mgr Mikałaj Hryńko

Uniwersytet Państwowy im. Janki Kupały w Grodnie (Białoruś)

Biblioteka Naukowa

ngrinko@grsu.by

mgr Uładzimir Kułażanka

Białoruski Uniwersytet Państwowy w Mińsku (Białoruś)

Fundamentalna Biblioteka

kulazhanka@bsu.by

\title{
OTWARTY DOSTĘP W SYSTEMIE KOMUNIKACJI NAUKOWEJ UNIWERSYTETÓW BIAŁORUSI
}

\author{
OPEN ACCESS IN THE SYSTEM OF SCIENTIFIC COMMUNICATION \\ OF BELARUSSIAN UNIVERSITIES
}

\begin{abstract}
Abstrakt
Celem artykułu jest analiza stanu i perspektyw wprowadzenia zasad otwartego modelu nauki do systemu komunikacji naukowej Białorusi. Wiąże się to z opracowaniem i wdrożeniem nowych narzędzi do promowania wyników pracy naukowej w globalnej przestrzeni informacyjnej. Zwrócono uwagę na brak krajowej strategii i nierównomierne wprowadzenie narzędzi komunikacji naukowej. Praktycznie zasada otwartego dostępu do publikacji jest najbardziej aktywnie wdrażana poprzez rozwój repozytoriów uniwersyteckich oraz projektów agregacji danych z repozytoriów otwartego dostępu.
\end{abstract}

Słowa kluczowe: otwarty dostęp do publikacji naukowych, otwarta nauka, repozytoria uniwersyteckie, Białoruś, nauka, edukacja.

\begin{abstract}
The purpose of the article is to analyze the state and prospects of the implementation of the principles of an open model of science in the system of scientific communication in Belarus. This is in response to the development and implementation of new tools to promote the results of
\end{abstract}


scientific work in the global information space. We drew attention to the lack of a national strategy and uneven implementation of scientific communication tools. In practice, the principle of open access for publications is most actively implemented through the development of University repositories and projects of data aggregation from open access repositories.

Keywords: open access to scientific publications, open science, University repositories, Belarus, science, education.

\section{Model komunikacji naukowej jako element krajowego systemu innowacji}

W latach 1960-1980 w Związku Socjalistycznych Republik Radzieckich powstał jeden $z$ najbardziej rozwiniętych ówczesnych systemów informacji naukowej i technicznej. Zasada budowy tego systemu odpowiadała strukturze zarządzania gospodarką narodową, z odpowiednimi podsystemami zorganizowanymi według cech terytorialnych, dziedzinowych, typów dokumentów i usług informacyjnych.

Charakterystyczną cechą systemu był hierarchiczny algorytm procesów wykorzystywanych do pracy z opublikowanymi i niepublikowanymi krajowymi i zagranicznymi źródłami dokumentacji. Zasadą było jednorazowe wpisanie i przetwarzanie zawartych w nich informacji, dostępnych w wyspecjalizowanych centrach informacji: instytutach, bibliotekach, archiwach, przedsiębiorstwach. Powstał w ten sposób jednolity system źródeł otwartej informacji, niezależnie od miejsca ich przechowywania.

Po upadku Związku Radzieckiego w większości krajów postradzieckich zasadnicze wysiłki miały na celu zminimalizowanie negatywnych konsekwencji związanych z zerwaniem więzi z głównymi i dziedzinowymi centrami informacji, podziałem wspólnych systemów informacyjnych, gwałtownym spadkiem nabywania dokumentów, zwłaszcza zagranicznych.

Z kolei duża eksplozja informacji i szybki rozwój technologii informacyjno-komunikacyjnych, które obserwujemy w ostatnich dziesięcioleciach, doprowadziły do jeszcze poważniejszych zmian w dziedzinie komunikacji naukowej, jak też $\mathrm{w}$ formach i metodach agregacji, przechowywania 
i przekazywania informacji naukowej, co niektórzy eksperci określają jako „drugą cyfrową rewolucję nauki”.

Wraz z pojawieniem się Internetu „pierwsza cyfrowa rewolucja nauki” lub „digitalizacja” zachodząca w procesach naukowych znacznie zmieniła codzienną praktykę gromadzenia, analizowania i prezentowania wyników działalności naukowej. I chociaż doprowadziło to do rozpowszechnienia czasopism elektronicznych, nie zmieniło zasadniczo tradycji dzielenia się wynikami badań za pośrednictwem publikacji naukowych.

Dzięki „drugiej cyfrowej rewolucji naukowej” podstawowe dane naukowe, metody badawcze, a także publikacje naukowe mogą być oddzielnie umieszczone w otwartym dostępie, co w opinii społeczności naukowej znacznie rozszerza możliwości stymulowania nowych badań oraz wyjścia z nimi poza środowisko akademickie.

W kontekście e-nauki i otwartego dostępu widoczność oraz wpływ wyników naukowych, a także danych badawczych stały się ważnymi aspektami rozpowszechniania informacji wśród użytkowników i społeczeństwa. Celem tej ogólnej tendencji w gospodarce jest zwiększanie wpływu nauki na procesy innowacyjne i ich wartość ekonomiczną. W związku z tym najbardziej aktywni przedstawiciele nauki zaczęli zastanawiać się nad możliwością skutecznego wykorzystania najnowszych form komunikacji internetowej w pracy badawczej. W ten sposób powstała koncepcja, której celem jest otwarte udostępnienie wyników badań naukowych i ich rozpowszechnianie. Sugeruje się umieszczenie w otwartym dostępie nie tylko publikacji, ale również oprogramowania oraz podstawowych danych naukowych.

Korzyści z rozpowszechniania wyników naukowych w otwartym dostępie są oczywiste. Otwarty dostęp sprawia, że publikacja jest znacznie bardziej widoczna dla innych naukowców, praktyków i kadry zarządzającej. Wiele badań naukowych wykazało, że artykuły publikowane w otwartym dostępie są wyświetlane i wykorzystywane częściej niż prace dostępne tylko w ramach płatnej subskrypcji ${ }^{2}$. Ponadto otwarty dostęp niewątpliwie

1 L. Lyon: Transparency: the emerging third dimension of Open Science and Open Data. „LIBER Quarterly” Vol. 25(4) (2016), s. 153-171. DOI: http://doi.org/10.18352/ lq.10113. Tryb dostępu: https://www.liberquarterly.eu/articles/10.18352/lq.10113/ [30 lipca 2018].

2 O. V. Moskaleva: Open access publications in Web of Science - review of journals. World-Class Scientific Publication - 2018: Editorial Policy, Open Access, Scientific Communications: Proc. 7th Int. Sci.\& Pract. Conf., Moscow, April 24-27, 2018. Moscow 2018, 
przyczynia się do szerszego dialogu między naukowcami, także w kontekście interdyscyplinarnym i transgranicznym. Otwarty dostęp również zmniejsza nierówność $\mathrm{w}$ dostępie do wiedzy z powodu braku lub bardzo niskiego finansowania zasobów informacyjnych w niektórych instytucjach.

Jednocześnie otwarty dostęp do pewnego stopnia przyczynia się do poprawy zarządzania nauką, pozwala uniknąć powtarzania tematów naukowych. Daje możliwość oceny wykorzystania publikacji poszczególnych naukowców oraz nawiązania kontaktów z sektorem gospodarczym.

Tak więc pojęcie „otwartej nauki” stosunkowo szeroko już stosowane $\mathrm{w}$ praktyce światowej, może zasadniczo zmienić w nieodległym czasie funkcje istniejących narzędzi do zarządzania informacją naukową i edukacyjną na Białorusi.

Ważne jest, że rozpowszechnianie modelu otwartej nauki odbywa się równolegle ze znacznym fizycznym wzrostem ilości informacji naukowej. Według Raportu UNESCO na temat nauki, publikowanego co pięć lat ${ }^{3}$, w 2014 r. w badania naukowe na całym świecie było zaangażowanych około 7,8 mln. pracowników naukowych. Od 2007 r. liczba ta wzrosła o $21 \%$. $\mathrm{Na}$ Białorusi, według krajowego portalu statystycznego z 2017 r., w nauce było zatrudnionych ponad 26,5 tys. osób w 454 organizacjach (w tym w 51 szkołach wyższych było zatrudnionych 1,3 tys. doktorów habilitowanych i 8,5 tys. doktorów).

Rosnąca liczba naukowców znajduje również odzwierciedlenie w gwałtownym wzroście liczby publikacji naukowych. Obecnie na świecie ukazuje się ponad 100 tys. międzynarodowych czasopism naukowych, w których co miesiąc publikuje się około 1,27 mln artykułów. Do najbardziej aktywnych należą: Chiny, Stany Zjednoczone i Indie. W 2016 r. chińscy naukowcy opublikowali 426 tys. artykułów naukowych indeksowanych w bazie Scopus, co stanowi około 18,6\% całości piśmiennictwa światowego. Stany Zjednoczone były na drugim miejscu - opublikowano 409 tys. prac, na trzecim miejscu znalazły się Indie ze 110 tys. publikacji ${ }^{5}$. Warto zauwa-

s. 109-114. DOI: http://doi.org/10.24069/konf-24-27-04-2018.20. Tryb dostępu: https:// rasep.ru/images/materials/konf2018/109-114.pdf [30 lipca 2018].

3 UNESCO science report: towards 2030. (2015). Tryb dostępu: https://unesdoc.unesco. org/ark:/48223/pf0000235406 [5 sierpnia 2018].

4 Narodowy Komitet Statystyczny Republiki Białorusi. Tryb dostepu: http://www.belstat. gov.by/ofitsialnaya-statistika/realny-sector-ekonomiki/nauka-i-innovatsii/godovye-dannye/kadry-nauki-v-2017-godu/ [5 sierpnia 2018].

5 Science \& Engineering Indicators. National Science Foundation. (2018). Tryb dostępu: https://www.nsf.gov/statistics/2018/nsb20181/report/sections/academic-research-and-development/outputs-of-s-e-research-publications [30 lipca 2018]. 
żyć, że dziesięć lat temu publikacje chińskie stanowiły tylko 5\% światowych zasobów informacyjnych. Inne kraje publikują znacznie mniej. Warto zaznaczyć, że Polska zajmuje 17 miejsce pod względem liczby publikacji, Rosja 10, a Ukraina 43.

Udział prac naukowców z Białorusi indeksowanych przez bazę Scopus w 2016 r. wynosił zaledwie 0,065\% w stosunku do całej zawartości bazy, czyli 1554 artykuły. Według Web of Science (WoS), w tym samym okresie odnotowano 1397 publikacji białoruskich. Pod względem liczby publikacji, Białoruś zajmuje dopiero 65 miejsce na świecie. Można zatem stwierdzić, że przy stosunkowo niewielkim rocznym przyroście liczby publikacji, białoruska nauka nie jest jeszcze wystarczająco zintegrowana $z$ tempem rozwoju światowej nauki.

Równie ważną zmianą jest umiędzynarodowienie nauki. Duże projekty naukowe mogą być częściej wdrażane w ramach międzynarodowej współpracy naukowej, a angielski język publikacji stał się jednym z najważniejszych czynników międzynarodowego wpływu. Na przykład z publikacji rosyjskich badaczy indeksowanych przez międzynarodową bazę danych WoS Core Collection w 2010 r. tylko około 5\% było w języku rosyjskim, podczas gdy na początku lat 70 . XX w. ponad $80 \%$ takich publikacji było w języku rosyjskim ${ }^{6}$. Jednocześnie znaczna liczba publikacji naukowych na Białorusi nadal powstaje w języku białoruskim lub rosyjskim.

Biorąc zatem pod uwagę główne trendy w rozwoju nauki światowej, można stwierdzić, że obecnie Białoruś nie ma jednego systemu informacyjnego, który zapewnia skuteczny dostęp do krajowych zasobów informacyjnych i interakcji z globalną przestrzenią informacyjną. Należy też uznać, że brak jest strategii wprowadzania zasad otwartego modelu nauki.

Rozpowszechnianie zasad otwartej nauki i wprowadzanie nowych narzędzi komunikacji naukowej w białoruskim środowisku akademickim i uniwersyteckim odbywa się nierównomiernie, istnieje zatem niewątpliwa potrzeba opracowania strategii w tym zakresie.

6 O. Kirchik, Y. Gingras, V. Larivière: Changes in Publication Languages and Citation Practices and Their Effect on the Scientific Impact of Russian Science (1993-2010). Tryb dostępu: http://www.ost.uqam.ca/Portals/0/docs/articles/2012/Russie_jasist.pdf [30 lipca 2018]. 


\section{Strategia otwartej nauki w działalności bibliotek uniwersyteckich na Białorusi}

W związku z wymienionymi zmianami w kierunkach rozwoju nauki na świecie białoruski system szkolnictwa wyższego uruchomił wiele projektów dotyczących tworzenia i rozwoju infrastruktury dla otwartej nauki. Od 2010 r. w Białoruskim Uniwersytecie Państwowym (BUP) w Mińsku zaczęła działać „Biblioteka Elektroniczna BUP”, która obecnie zawiera ponad 150 tys. dokumentów. Biorąc pod uwagę liczbę dokumentów i stopień otwartości, według międzynarodowego rankingu Web of Repositories, jest ona jedną z najlepszych uniwersyteckich bibliotek elektronicznych na świecie. W sumie na Białorusi istnieją 24 instytucjonalne repozytoria otwartego dostępu w 51 instytucjach szkolnictwa wyższego, które zawierają ponad 360 tys. dokumentów. Dla porównania, w Rosji ponad 800 instytucji szkolnictwa wyższego ma w przybliżeniu taką samą liczbę repozytoriów i dokumentów.

Należy zauważyć, że umieszczanie publikacji w repozytorium instytucjonalnym skutecznie przyczynia się do wzrostu pozycji i znaczenia uczelni w międzynarodowych rankingach, przede wszystkim w rankingu Webometrics.

$\mathrm{W}$ ostatnim czasie na Białorusi powstały nowe inicjatywy w zakresie otwartej nauki. Jedną z nich jest projekt stworzenia krajowego agregatora otwartych repozytoriów, którego celem jest nie tylko integracja zasobów informacyjnych, ale także dostarczanie informacji, oprogramowania i wsparcia metodologicznego dla procesów naukowych i edukacyjnych. Takim projektem jest opracowanie zautomatyzowanego zintegrowanego systemu wsparcia informacji dla procesów naukowych i edukacyjnych w oparciu o otwarte zasoby AIRO. Celem rozpoczętego w 2018 r. $^{7}$ projektu jest połączenie zasobów repozytoriów białoruskich instytucji edukacyjnych, bibliotek, organizacji naukowych i innych organizacji $\mathrm{w}$ ramach otwartego dostępu i uproszczenie procesu wyszukiwania publikacji. Jako platformę do tworzenia krajowego agregatora zasobów informacyjnych otwartego dostępu na Białorusi ustalono oprogramowanie DSpace, które jest rozpowszechniane na warunkach licencji wolnego oprogramowania. Krajowy system agregujący przeznaczony jest do: automatyzacji tworzenia

7 Zob. AIRO - Zautomatyzowany zintegrowany system wsparcia informacji dla procesów naukowych i edukacyjnych oparty na zasobach otwartego dostępu. Tryb dostępu: http://airo.unibel.by/ [5 sierpnia 2018]. 
metadanych elektronicznych zasobów informacyjnych sfery naukowej i edukacyjnej, szybkiego dostępu do opisów elektronicznych zasobów informacyjnych sfery naukowej i edukacyjnej w oparciu o technologie internetowe, skracania czasu wyszukiwania, integracji metadanych zawartych w repozytoriach, dostarczania użytkownikom wygodnych i wydajnych funkcji wyszukiwania informacji o atrybutach metadanych, zwiększających efektywność ich wykorzystania w badaniach naukowych oraz działalności edukacyjnej, automatyzacji zbierania metadanych, polepszenia jakości tworzonych zasobów informacyjnych, zapewnienia bezpieczeństwa kopii zapasowych dokumentów cyfrowych ${ }^{8}$.

Dalszy rozwój systemu wiąże się z możliwością identyfikacji każdej publikacji za pomocą cyfrowych identyfikatorów obiektów $\mathrm{DOI}^{9}$ oraz systemu identyfikatorów autorów ORCID ${ }^{10}$. System może stać się podstawą do stworzenia krajowego systemu CRIS ${ }^{11}$, w którym będą gromadzone informacje o wszystkich publikacjach białoruskich badaczy, w tym pełne teksty lub, jeśli to możliwe, odesłania do nich.

Aby zwiększyć konkurencyjność białoruskich badań naukowych, należy stworzyć warunki ujawniania, czyli otwarcia danych naukowych. W tym celu biblioteki mogą wykonywać następujące czynności:

- dołączanie do międzynarodowego ruchu otwartych danych w dziedzinie nauki i edukacji;

- opracowanie polityki w zakresie otwartych danych naukowych na poziomie państwowym, ujawnianie zasad, technologii, standardów opisywania i identyfikowania danych, pozwalających na integrację

8 D. Kachan, A. Bogatko, I. Bogatko, S. Enin, U. Kulazhanka, V. Lazarev, P. Lis, A. Skalaban, I. Yuryk: Integration of information resourcesof open access to provide the scientificand educational process in the institutionsof higher education. „Open education” Vol. 22, nr 4 (2018), s. 53-63. DOI: http://dx.doi.org/10.21686/1818-4243-2018-4-5363. Tryb dostępu: http://elib.bsu.by/bitstream/123456789/204331/1/53-63.pdf [5 sierpnia 2018].

9 DOI (ang. Digital Object Identifier) - cyfrowy identyfikator dokumentu elektronicznego. Tryb dostępu: https://en.wikipedia.org/wiki/Digital_object_identifier [5 sierpnia 2018].

10 ORCID (ang. Open Researcher and Contributor ID) - kod alfanumeryczny stworzony dla unikalnego identyfikowania autorów i współautorów publikacji naukowych i akademickich. Tryb dostępu: https://en.wikipedia.org/wiki/ORCID [5 sierpnia 2018].

11 CRIS (ang. Current Research Information System) - baza danych lub inny system informacyjny do przechowywania, zarządzania i wymiany metadanych kontekstowych dla działalności badawczej. Tryb dostępu: https://en.wikipedia.org/wiki/Current_research_information_system [5 sierpnia 2018]. 
z globalną przestrzenią informacyjną, a także jasno zdefiniowanych kategorii zbiorów danych w zależności od ich statusu w zakresie ujawniania (licencjonowanie, etyka badawcza);

- stworzenie krajowego portalu otwartych danych naukowych na Białorusi.

Oprócz promowania i agregowania publikacji naukowych, obecnie na Białorusi aktywnie dyskutuje się nad potrzebą stworzenia białoruskiego repozytorium otwartych (pierwotnych) danych naukowych. Nastąpiły poważne zmiany w ruchu na rzecz otwarcia dostępu do niektórych białoruskich czasopism naukowych. Od kilku lat ważne czasopisma białoruskie umieszczają swoje kopie cyfrowe $\mathrm{w}$ repozytoriach instytucjonalnych, a także w Rosyjskim Indeksie Cytowań Naukowych (RICN) lub w różnych systemach bibliotek elektronicznych. Uniwersytety, przy aktywnym udziale bibliotek, wykonały znaczną pracę $\mathrm{w}$ celu dostosowania czasopism do wymagań dotyczących włączenia do bazy danych Scopus i WoS.

Oprócz rozwoju infrastruktury dla otwartej nauki biblioteki uniwersyteckie pracują również nad informowaniem społeczności akademickiej o możliwościach narzędzi komunikacji naukowej i otwartego dostępu. Aby pomóc pracownikom naukowym i pedagogicznym BUP w przygotowywaniu wysokiej jakości publikacji naukowych, zostało utworzone Centrum Kompetencji Naukowych i Komunikacji, funkcjonujące jako witryna wirtualnej pomocy, łącząca odpowiedzi na główne pytania stawiane przez pracowników naukowych ${ }^{12}$. W Centrum wdrożono pomysł stworzenia usługi doradczej - strona zawiera również dane kontaktowe ekspertów do spraw analizy naukowej, którzy mogą pomóc młodym naukowcom we wsparciu informacyjnym przy określaniu priorytetów i opracowywaniu strategii publikacji naukowych oraz rejestrowaniu i poszukiwaniu informacji w głównych bazach danych. Udostępniono również dane kontaktowe wybitnych naukowców mających doświadczenie w uczestnictwie w międzynarodowych projektach i publikujących w wiodących czasopismach indeksowanych przez Scopus i WoS.

Z ekspertami BUP mogą kontaktować się naukowcy z innych uniwersytetów, którzy szukają partnerów do wspólnych projektów, a także młodych naukowców, którzy chcą uzyskać porady doświadczonych kolegów na temat specyfiki działalności wydawniczej w poszczególnych dziedzinach nauki.

12 Zob. Szkoła komunikacji naukowej. Tryb dostępu: http://science.bsu.by/ [5 sierpnia 2018]. 
W ostatnich latach białoruskie uniwersytety aktywnie włączają się $\mathrm{w}$ ruch międzynarodowy $\mathrm{w}$ zakresie otwartego dostępu, tworząc sieć repozytoriów instytucjonalnych i włączając swoje czasopisma naukowe do otwartego dostępu. Można stwierdzić, że na Białorusi jest aktywnie tworzona niezbędna infrastruktura do promocji publikacji w globalnej przestrzeni naukowej. Przynosi to już wyniki uniwersytetom, uczonym, studentom i opinii publicznej, a dzięki stabilnemu finansowaniu i skutecznemu zarządzaniu, umożliwia białoruskiej nauce osiągnięcie jakościowo nowego poziomu.

\section{Wnioski}

Obecni dostawcy informacji spontanicznie kształtują zdolności współczesnego społeczeństwa do ich wykorzystania. Metody dostępu do informacji zasadniczo różnią się od tych, które stosowano dawniej, na przykład 10 lat temu. Charakteryzuje je rozwój nowych technicznych środków komunikacji oraz zmiany w postrzeganiu informacji i realizacji potrzeb informacyjnych.

Zatem zasoby edukacyjne i naukowe we współczesnych warunkach nie mogą istnieć w postaci różnych, odmiennych stron internetowych, muszą być częścią jednolitego systemu: portali naukowych i edukacyjnych z zasobami, których użycie jest konieczne w praktyce naukowej i edukacyjnej.

Nowoczesne podejście do budowania wirtualnego środowiska naukowego i edukacyjnego opiera się na łączeniu różnych zasobów i technologii z głęboką integracją zbiorów danych instytucjonalnych w struktury krajowe i międzynarodowe.

Nie mniej ważne dla skutecznego funkcjonowania różnych kompleksów naukowych i edukacyjnych zasobów informacyjnych jest rozpowszechnianie i konsolidacja prawna modelu otwartego dostępu do nauki oraz rozwój infrastruktury „otwartej” nauki na poziomie krajowym. Otwarty model nauki, otwarty dostęp do publikacji naukowych widoczny jest w krajach najbardziej aktywnych pod względem naukowym, takich jak: Chiny, Stany Zjednoczone czy państwa Unii Europejskiej. Model ten funkcjonuje w tych krajach od lat, zwiększając możliwości bezpłatnego dostępu do publikacji naukowych w skali międzynarodowej. 


\section{Bibliografia}

1. AIRO - Zautomatyzowany zintegrowany system wsparcia informacji dla procesów naukowych i edukacyjnych oparty na zasobach otwartego dostępu. Tryb dostępu: http://airo.unibel.by/ [5 sierpnia 2018].

2. Kachan D., Bogatko A., Bogatko I., Enin S., Kulazhanka U., Lazarev V., Lis P., Skalaban A., Yuryk I.: Integration of information resourcesof open access to provide the scientificand educational process in the institutionsof higher education. „Open education” Vol. 22, nr 4 (2018), s. 53-63. DOI: http://dx.doi. org/10.21686/1818-4243-2018-4-53-63. Tryb dostępu: http://elib.bsu.by/bitstream/123456789/204331/1/53-63.pdf [5 sierpnia 2018].

3. Kirchik O., Gingras Y., Larivière V.: Changes in Publication Languages and Citation Practices and Their Effect on the Scientific Impact of Russian Science (1993-2010). Tryb dostępu: http://www.ost.uqam.ca/Portals/0/docs/articles/2012/Russie_jasist.pdf [30 lipca 2018].

4. Lyon L.: Transparency: the emerging third dimension of Open Science and Open Data. „LIBER Quarterly” Vol. 25(4) (2016), s. 153-171. DOI: http:// doi.org/10.18352/lq.10113. Tryb dostępu: https://www.liberquarterly.eu/articles/10.18352/lq.10113/ [30 lipca 2018].

5. Moskaleva O. V.: Open access publications in Web of Science - review of journals. World-Class Scientific Publication - 2018: Editorial Policy, Open Access, Scientific Communications: Proc. 7th Int. Sci. \& Pract. Conf., Moscow, April 24-27, 2018. Moscow 2018, s. 109-114. DOI: http://doi.org/10.24069/ konf-24-27-04-2018.20. Tryb dostępu: https://rasep.ru/images/materials/ konf2018/109-114.pdf [30 lipca 2018].

6. Narodowy Komitet Statystyczny Republiki Białorusi. Tryb dostępu: http:// www.belstat.gov.by/ofitsialnaya-statistika/realny-sector-ekonomiki/nauka-i-innovatsii/godovye-dannye/kadry-nauki-v-2017-godu/ [5 sierpnia 2018].

7. Science \& Engineering Indicators. National Science Foundation. (2018). Tryb dostępu: https://www.nsf.gov/statistics/2018/nsb20181/report/sections/academic-research-and-development/outputs-of-s-e-research-publications [30 lipca 2018].

8. Szkoła komunikacji naukowej. Tryb dostępu: http://science.bsu.by/ [5 sierpnia 2018].

9. UNESCO science report: towards 2030. (2015). Tryb dostępu: https://unesdoc. unesco.org/ark:/48223/pf0000235406 [5 sierpnia 2018]. 